Article

\title{
Profiles of Mobile Phone Use, Cyberbullying, and Emotional Intelligence in Adolescents
}

\author{
Inmaculada Méndez ${ }^{1}{ }^{1}$, Ana Belén Jorquera ${ }^{1}$, Cecilia Ruiz Esteban ${ }^{1, *} \mathbb{C}$ and \\ José Manuel García-Fernández 2,*iD \\ 1 Department of Evolutionary and Educational Psychology, Faculty of Psychology, Campus Regional \\ Excellence Mare Nostrum, University of Murcia, 30100 Murcia, Spain; inmamendez@um.es (I.M.); \\ anabelen.jorquera@um.es (A.B.J.) \\ 2 Department of Developmental Psychology and Didactics, University of Alicante, 03080 Alicante, Spain \\ * $\quad$ Correspondence: cruiz@um.es (C.R.E.); josemagf@ua.es (J.M.G.-F.); Tel.: +34-868883461 (C.R.E.); \\ +34-965903400 (J.M.G.-F.)
}

Received: 28 October 2020; Accepted: 10 November 2020; Published: 12 November 2020

\begin{abstract}
The use of mobile phones has great benefits for communication. However, evidence has shown that problematic use, such as cyberbullying, can also be associated with mobile phones. In this sense, emotional regulation plays an important role. The objective of this study was to identify different groups that varied in terms of conflicts related to problematic mobile phone use (namely, maladaptive communication and emotional patterns). Furthermore, the study aimed to examine whether there were significant differences in the dimensions of emotional intelligence and cyberbullying between adolescents with a mobile phone use problem. The study participants were 810 students aged between 12 and 16 years. The Emotional Coefficient Inventory questionnaire about cyberbullying and a questionnaire on experiences related to mobile phones were used. The cluster analysis identified three different types of mobile phone use: A group displaying no problematic use, a group displaying moderately problematic use, and a group displaying problematic use. The study results motivate carrying out stress management programs, emotional re-education, and other actions that reinforce emotional intelligence.
\end{abstract}

Keywords: mobile use; emotion regulation; adolescence; cyberbullying; mental health

\section{Introduction}

The adolescent stage is a crucial period of life in which the search for sensations, together with impulsivity, can lead adolescents to be involved in certain problematic or risky behaviors [1,2]. In recent years, it has been found that the problematic use of mobile phones has increased in adolescents [2-4]. Several investigations have shown that the problematic use of mobile phones in adolescents is associated with increased drug use, low school achievement, and poor interpersonal relationships [5-7], low self-esteem, greater impulsivity, anxiety [8], and low family cohesion, among others [7-9].

Teenagers usually make recreational or communicative use of their mobile phones (they can use social networks, send messages, listen to music, etc.) $[2,4,10]$. However, if recreational or communicative use becomes excessive and uncontrollable, this leads to the teen seeking short-term pleasurable rewards (a positive booster), thus assuming a loss of control and producing a dependence on the mobile phone [11]. In this regard, research has found that adolescents with more problematic mobile phone use often use it as a buffer from emotional stress (a negative booster) and as a way to evade and alleviate emotional discomfort (loneliness, boredom, irritability, nervousness, etc.) $[5,9,11-13]$. Therefore, teens with a greater emotional mismatch are often more prone to engage in the problematic use of new technologies [1,14], and thus, enter a vicious circle to alleviate emotional distress through problematic mobile phone use $[5,11,15-17]$. It appears that dysfunctional internal and external emotional regulation 
predict problematic mobile phone use among adolescents [18]. It has also been shown that people with problematic internet use have greater difficulties in regulating their emotions [19-23]. Similarly, it has been shown that subjects with problematic mobile phone use often use such devices as an effective way to regulate their emotions [24]. As such, the problematic use of the mobile phone affects emotional intelligence and self-regulation, and therefore, the individual well-being and quality of life of adolescents [25].

Therefore, the mobile phone becomes a necessary channel for communication, but it can become problematic $[2,3,8]$. Problematic mobile phone use is often associated with the inability to disconnect or turn it off to avoid missing experiences or information that other people are sharing. This means that teens may have sleep problems and increased anxiety due to their fear of being disconnected $[9,26]$, which, coupled with their lack of maturity, can even cause some psychological discomfort [1].

Most teens prefer communication using mobile phones over face-to-face communication [13]. During digital communication, the user does not need to identify themselves, therefore, the teen can create an idealized character for socializing and establishing interpersonal relationships on social networks, which cannot be done using face-to-face communication $[3,11,27]$. Interpersonal relationships in the digital world represent a change in the temporal and spatial conception, where there appears to be a feeling of immediacy and acceleration of the processes involved $[16,28]$. This is a form of interaction in which mismatched behaviors may appear (e.g., saying things on a mobile phone that would not be said in person), which can lead to conflicts in interpersonal relationships $[4,12,13,15,28]$.

Therefore, the use of mobile phones provides a way to socialize and search for or create one's identity [13]. Adolescents with a form of identity confusion often present a problematic pattern of new technology use [29]. As part of the search for identity, teens can share personal and emotional information online without being aware of the risks that the loss of privacy and anonymity can entail, where it is even possible to lose control of what is shared on the Internet $[30,31]$. By communicating and sharing such information online, the possibility of a privacy violation via disseminating information without the consent of victims presents an increased risk of being victimized by cyberbullying [32,33]. Therefore, cyberbullying tends to occur with a greater probability among adolescents who share a technological culture since it is an extension of their personal history and their social relationships [31]. That is, cyberbullying is a virtual extension of the harassment suffered in person [30-32,34-38]. In this sense, social media is a mode of expression of emotions $[15,16,28]$ that has been associated with aggressive behaviors in schoolchildren [38]. Interpersonal conflicts arising from the problematic use of new technologies play an important role in cyberbullying, where the existence of difficulties in interpersonal relationships can favor rejection or social exclusion [39].

Thus, there is evidence that the problematic use of new technologies is linked to problems of bullying and cyberbullying [40-42]. Those teens with their own phones with Internet access have greater involvement in the role of a cyberbully aggressor [43-45]. In previous research, we have shown that teens with increased problematic mobile phone use are involved in bullying and cyberbullying situations [42]. However, it is also understood that new technologies are used as a buffer to minimize aggression or prevent impulsivity rather than genuinely regulating emotions [32]. The lack of emotional regulation and stress is the basis of conflicts related to Internet use [13], which can lead to behavioral violence. Thus, it has been shown that the problematic use of new technologies has been associated with emotionally unstable, impulsive subjects with low subjective well-being and less family social support [14]. Therefore, there is a need to inquire into the emotions of teenagers based on their profiles of mobile phone use.

The objective of this study was to identify different groups that varied in terms of the conflicts related to problematic mobile phone use (maladaptive communication and emotional patterns). Furthermore, this study aimed to examine whether there were significant differences in the dimensions of emotional intelligence and cyberbullying between adolescents with a mobile phone use problem. 


\section{Materials and Methods}

\subsection{Participants}

A total of 1021 adolescents were approached to take part, of which 211 were finally excluded because they did not provide informed consent or because the questionnaires were partially answered. The participants included in the study were 810 students belonging to secondary schools from different geographical areas of the region of Murcia in Spain (with an average socioeconomic level). This is a representative sample of secondary school students in the region of Murcia (with a margin of error of $5 \%$ ). The participants were between 12 and 16 years old, where $52.2 \%$ were girls. A total of $77.9 \%$ had not submitted for a repetition of a school year and $4.8 \%$ were born outside of Spain.

\subsection{Instruments}

The four assessment instruments used in the study are described below.

First, tests to establish the socio-demographic variables were administered. The test asked for responses regarding the following sociodemographic and academic issues: Gender (male/female), age, course repetition (yes/no), and country of birth.

Second, the Spanish version of the Emotional Quotient Inventory: Youth Version (EQ-i: YV) was used [46]. It consists of 60 items with a rating scale that ranged from 1-very seldom true or not true for me to 4 -very often. The instrument consisted of the following five dimensions: Intrapersonal (refers to self-awareness and self-expression, e.g., I can easily talk about my feelings), interpersonal (refers to social awareness and interpersonal relationships, e.g., I care what happens to other people), adaptability (refers to the ability to manage change, e.g., It's easy for me to understand new things), stress management (it refers to the capacity for regulation and emotional management, e.g., I can be calm when I get angry), and general mood (self-motivation, e.g., I know that things will work out). The Cronbach's $\alpha$ coefficient was adequate, both during validation $(\alpha=0.89)$ [47] and in this study $(\alpha=0.86)$.

Third, the Questionnaire of Experiences Related to Phones (CERM) [48] was used. The instrument consists of 10 items and measures mobile phone abuse using a four-point Likert scale. The questionnaire consists of two factors: Conflicts, which are related to the problematic use of mobile phones (e.g., Do you stop going out with your friends to spend more time using the mobile?), and communicational use, which is related to communicational and emotional problems associated with the problematic use of mobile phones (e.g., How often do you say things on your mobile that you wouldn't say in person?). The Cronbach's $\alpha$ coefficient was adequate for conflicts $(\alpha=0.81)$ and communicational use $(\alpha=0.75)$ during validation [48]. The Cronbach's $\alpha$ coefficients were 0.91 for conflicts and 0.89 for communicational use in this study.

Fourth, the perceptions of cyberbullying were evaluated through the revised School Violence Questionnaire [49]. It consists of 31 items using a response scale from 1-never to 5-always. For our study, we selected the factor of perceived violence through the use of new information technologies or cyberbullying (includes violent behaviors through electronic means, mainly the mobile phone and internet). In this study, the Cronbach's $\alpha$ coefficient was 0.87 . An example element of the dimension used for this questionnaire is "Students post offensive photos or videos of classmates on the Internet."

\subsection{Procedure}

This is a cross-sectional descriptive study. First, ethics committee authorization for the development of the research was granted. Next, the secondary schools to be used in the sample were decided upon. Once these schools had been selected, an interview was conducted with the directors and/or counselors from these educational centers to present the objectives of the research, describe the assessment instruments, request their permission, and promote their collaboration. Authorization was subsequently obtained from the students and their parents or legal representatives. In the session used to apply the testing instruments (with a duration of $50 \mathrm{~min}$ ), the students were informed of the 
voluntary, anonymous, and confidential nature of the study, as well as its objectives. The answer sheets were then coded and entered into a database for statistical treatment.

\subsection{Data Analysis}

In this study, latent profile analysis was used to identify the subgroups of students [50]. After analyzing the lowest values of the Bayesian information criterion (BIC), the best model was chosen [51]. The student groups were defined based on their different mobile phone usage, namely, in terms of conflicts (conflicts related to the problematic use of the mobile phone) and communicational use (communicational and emotional use). Pearson correlations and descriptive statistics were calculated. A multivariate analysis of variance (MANOVA) was conducted to examine the differences in the dimensions of emotional intelligence between the groups. The partial eta squared $\left(\eta_{p}{ }^{2}\right)$ was used to calculate the magnitude of the differences. Furthermore, Cohen's $d$ was estimated to identify the effect size [52]. The MPlus (Muthén and Muthén, Los Angeles, CA, USA) [51] package and the Statistical Package for the Social Science version 23.0 (IBM Corp., Armonk, NY, USA)was used in this study.

\subsection{Ethics Approval}

For this study, the protocol was approved by the ethics committee of the University of Murcia (ID: 2627/2019). After permission from the schools, informed consent was obtained from all participants and their parents or legal representatives to participate in the study.

\section{Results}

Table 1 shows the Pearson correlations of the conflicts related to the problematic use of mobile phones (conflicts) and the problems due to the communicational and emotional use of mobile phones (communicational use) with the dimensions of emotional intelligence and cyberbullying. With the exception of the intrapersonal dimension, the Pearson correlations were positive or negative and statistically significant.

Table 1. Pearson correlations between the emotional intelligence and cyberbullying variables.

\begin{tabular}{ccc}
\hline Variable & Conflicts & Communicational Use \\
\hline Intrapersonal & 0.055 & 0.021 \\
Interpersonal & $-0.104^{* *}$ & $-0.136^{* *}$ \\
Stress management & $-0.124^{* *}$ & $-0.152^{* *}$ \\
Adaptability & $0.337^{* *}$ & $0.313^{* *}$ \\
General mood & $-0.151^{* *}$ & $-0.201^{* *}$ \\
Cyberbullying & $0.410^{* *}$ & $0.306^{* *}$ \\
\hline & Note: ${ }^{* *} p<0.01$.
\end{tabular}

Table 2 shows the models that were examined, which involved two to six clusters. The four-, five-, and six-cluster models were discarded since, although they presented a lower BIC and a higher entropy, they had a cluster with only 11 subjects (cluster 4) and the five- and six-cluster models had two groups with only a few subjects (see the size box in Table 2). From the remainder of the models, the three-cluster model had the lowest BIC and was, therefore, chosen. Cluster analysis of the latent profile analysis identified three different types of use for mobile phones: (a) A first group was called "non-problematic use" (534 students), which had low levels of conflict related to the misuse of mobile phones and low levels of communication and emotional use, (b) a second group was called "moderate problematic use" (209 students), which was characterized by a moderate level of conflicts related to mobile phone abuse and a moderate level of communication and emotional use, (c) a third group of called "problematic use" (67 students), which had high levels of conflict related to the misuse of mobile phones and high levels of communication and emotional use (Figure 1). 
Table 2. The fits of the results of the latent profile analysis of the study.

\begin{tabular}{ccccccccc}
\hline $\begin{array}{c}\text { Models } \\
\text { (Clusters) }\end{array}$ & AIC & BIC & $\begin{array}{c}\text { BIC } \\
\text { (Adjusted) }\end{array}$ & $\begin{array}{c}\text { LRT } \\
\boldsymbol{p}\end{array}$ & $\begin{array}{c}\text { LRT } \\
\text { (Adjusted) }\end{array}$ & BLRT & Entropy & Size \\
\hline 2 & 4156.294 & 4189.173 & 4189.173 & 0.0000 & 0.0000 & 0.0000 & 0.900 & 0 \\
3 & 4023.664 & 4070.635 & 4038.879 & 0.0280 & 0.0319 & 0.0000 & 0.781 & 0 \\
4 & 3924.906 & 3985.967 & 3944.685 & 0.0000 & 0.0000 & 0.0000 & 0.816 & 1 \\
5 & 3876.973 & 3952.125 & 3901.316 & 0.0058 & 0.0071 & 0.0000 & 0.870 & 2 \\
6 & 3826.933 & 3916.176 & 3855.840 & 0.0000 & 0.0000 & 0.0000 & 0.841 & 2 \\
\hline
\end{tabular}

Note: AIC-Akaike information criterion, BIC-Bayesian information criteria, LRT-Vuong-Lo-Mendell-Rubin likelihood ratio test, BLRT—bootstrap likelihood ratio test. The bold model 3 indicates the best fitting model.

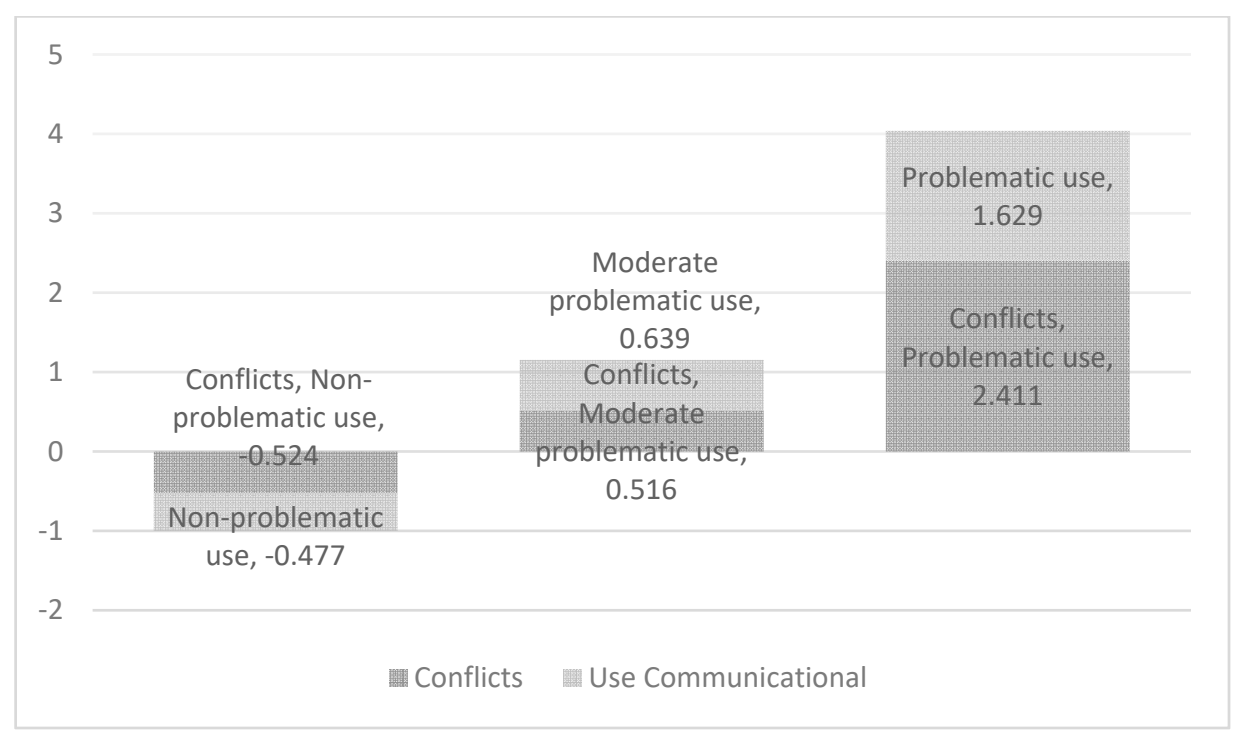

Figure 1. Graphical representation of the three-cluster model.

Table 3 provides the results of the MANOVA significant differences that were found between the three groups of mobile phone use problems regarding the dimensions of emotional intelligence and cyberbullying.

Table 3. Means and standard deviations of the three groups of mobile phone use and values of the partial eta squared $\left(\eta_{p}^{2}\right)$ for emotional intelligence and cyberbullying.

\begin{tabular}{cccccccccc}
\hline & \multicolumn{2}{c}{ Group 1 } & \multicolumn{2}{c}{ Group 2 } & \multicolumn{2}{c}{ Group 3 } & \multicolumn{3}{c}{ Significance } \\
\cline { 2 - 10 } Variable & $\mathbf{M}$ & SD & $\mathbf{M}$ & SD & $\mathbf{M}$ & SD & $\boldsymbol{F}_{(\mathbf{2 . 8 0 7})}$ & $p$ & $\boldsymbol{\eta}_{\boldsymbol{p}}{ }^{2}$ \\
\hline Intrapersonal & 14.69 & 2.81 & 15.21 & 3.04 & 15.06 & 2.42 & 2.66 & 0.070 & 0.01 \\
Interpersonal & 41.78 & 6.94 & 40.42 & 6.41 & 38.56 & 6.69 & 8.34 & $<0.001$ & 0.02 \\
Adaptability & 30.19 & 7.05 & 28.89 & 5.90 & 26.40 & 6.34 & 10.63 & $<0.001$ & 0.03 \\
Stress management & 27.07 & 4.60 & 30.44 & 5.23 & 31.81 & 5.89 & 53.73 & $<0.001$ & 0.12 \\
General mood & 47.46 & 9.33 & 45.14 & 9.31 & 41.87 & 9.85 & 12.99 & $<0.001$ & 0.04 \\
Cyberbullying & 8.68 & 3.66 & 10.81 & 4.22 & 15.07 & 7.86 & 74.01 & $<0.001$ & 0.16 \\
\hline
\end{tabular}

Note: Group 1-non-problematic use, group 2-moderate problematic use, and group 3-problematic use.

In Table 4, the post-hoc comparisons showed that group 1 obtained significantly higher values of the interpersonal and general mood variables and significantly lower stress management scores than group 2 . 
Table 4. Cohen's values for the post-hoc contrast groups and $p$-values.

\begin{tabular}{cccc}
\hline Models & Group 1-Group 2 & Group 1-Group 3 & Group 2-Group 3 \\
\hline Intrapersonal & n.s. & n.s. & n.s. \\
Interpersonal & $0.20^{*}$ & $0.47^{* *}$ & n.s. \\
Adaptability & n.s. & $0.54^{* * *}$ & $0.41^{*}$ \\
Stress management & $0.70^{* * *}$ & $1.00^{* * *}$ & n.s. \\
General mood & $0.25^{*}$ & $0.60^{*}$ & $0.35^{* * *}$ \\
Cyberbullying & $0.56^{* * *}$ & $1.48^{* * *}$ & $0.80^{* * *}$ \\
\hline \multicolumn{2}{c}{ Note: $^{*} p<0.0,^{* *} p<0.01^{* * *} p<0.01$, n.s. - not significance. }
\end{tabular}

Group 1 obtained significantly higher values in the interpersonal, adaptability, and general mood variables and significantly lower values in stress management compared to group 3.

Group 2 obtained significantly higher values in the adaptability and general mood variables compared to group 3.

Furthermore, it was found that group 1 obtained significantly lower values than groups 2 and 3 in cyberbullying. Group 2 obtained significantly lower values than group 3 in cyberbullying.

\section{Discussion}

In this study, we identified three types of mobile phone use: a non-problematic use group, a moderately problematic use group, and a problematic use group. The MANOVA results revealed significant differences between the different groups of mobile phone use in the dimensions of emotional intelligence and cyberbullying.

Group 1 was characterized by better values regarding the interpersonal and general mood variables than group 2 and adaptability than group 3. Group 1 represented a profile of adolescents who did not present problematic use of mobile phones, with the ability to establish satisfactory interpersonal relationships, with the ability to listen to colleagues, and to put themselves in place. It was a profile that properly handled daily problems by knowing how to manage their emotions easily and did not need to manage stress or emotions through mobile phone use, unlike groups 2 or 3 . The group 1 profile had a greater ability to adapt by being more flexible and properly and positively managing problems, unlike group 3. Furthermore, they were less involved in cyberbullying situations.

Group 2 represented a profile of teenagers with moderately problematic mobile phone use that had more appropriate values in the adaptability and general mood variables than group 3 . Therefore, this was a profile of teenagers who had greater flexibility to adapt to daily changes, unlike group 3 . However, regarding the level of moderately problematic use of mobile phones and involvement in cyberbullying, this was a group of students at risk such that it is necessary to prevent these teenagers from losing control of their emotions and using mobile devices to manage their emotions, just as in the case of group 3.

In the case of group 3, this was a group of students with a problematic profile of mobile phone use, where they presented high values regarding stress management, unlike groups 1 and 2 . Therefore, this was a group of students who had problems managing stress and continually resorted to the use of mobile phones to dampen such emotions of impulsivity and irritability. This was in line with the data obtained regarding cyberbullying, where group 3 had higher values because it engaged in more cyberbullying situations relative to groups 1 and 2 . In the case of the adolescents in group 3, it was clear that they had low values in the interpersonal, adaptability, and general mood variables, unlike group 1. Therefore, this was a profile of teenagers with difficulties in interpersonal relationships, with difficulties in identifying the emotions of others, that were inflexible, that had difficulty managing changes, and presented inefficiencies in their emotional management.

These results are in line with previous research that showed that teens with problematic mobile phone use often use their mobile phone as a buffer against emotional tension, i.e., as a way to evade and alleviate emotional discomfort $[5,9,11-13,16]$, therefore, teens who have exhibited a more problematic 
use of mobile phones have an emotional mismatch that leads them to use a mobile phone to relieve discomfort and to manage stress, unlike those with non-problematic or moderately problematic use $[1,14,24]$. Thus, it has been shown that emotional regulation is relevant in mobile phone use since those adolescents who had non-problematic use had adequate values compared to adolescents with moderately problematic use [18-23]. In addition, problematic mobile phone use has been associated with increased involvement in cyberbullying [40-45]. This is in line with research that suggests that the problematic use of new technologies is done to alleviate aggression or prevent impulsivity [32]. Thus, the lack of emotional regulation and stress is the basis of conflicts related to the use of the Internet [13], leading to school violence behaviors.

Therefore, the results motivate considerations of the need to address educational actions that promote the proper management of tension or emotional discomfort by preventing adolescents from resorting to the problematic use of mobile phones to dampen emotions and tensions $[5,7,11,16]$. Educational programs aimed at emotional self-regulation and the promotion of emotional intelligence need to be promoted, which will, in turn, result in an increase in the well-being and quality of life of adolescents [25]. In short, an increase in emotional intelligence can mitigate the negative effects on cyberbullying victims [53].

It is also of interest to promote skills for conflict resolution in students and to provide them with communication skills, healthy leisure activities, etc. $[13,54]$. Thus, it is necessary to foster adequate coexistence relationships by avoiding conflicts that can lead to bullying or cyberbullying situations. Preventive programs, such as the ConRed cyberbullying program [55] or the Asegúrate Program [56,57], allow for the reduction of situations of school violence and a reduction in the dependence on new technologies for those involved in cyberbullying situations. Effective programs against bullying and cyberbullying that stand out in Spain include Cyberprogram 2.0 and the Cooperative Cybereduca 2.0 video game [58] and Program Prev@cib [59].

Similarly, family awareness is needed for the early detection of problematic mobile phone use to prevent them from becoming abusive and having important negative implications for adolescent well-being in all its areas $[1,5,11]$, programs that provide collaboration between families and schools are also needed [9].

The limitations of this study include the fact that this was a cross-sectional study with the use of instruments that may suffer from a social desirability bias. Longitudinal studies are needed [6], where it is necessary to find out whether these profiles continue to be maintained at later stages. It would also be of interest to gather information on the management of emotions through sports activities, to take into account parental educational styles [9], and even to gather information on the relationships of emotion management with drug use, eating disorders, and compulsive spending [60].

\section{Conclusions}

This study found that adolescents with a problematic mobile phone usage profile had a greater emotional mismatch [1], as well as increased involvement in cyberbullying situations. The problematic use of mobile phones has been associated with a mismatch in the management of emotional tension, as teens often resort to the use of such devices to minimize the tension or emotional discomfort it presents. Therefore, some teens use mobile phones as a buffer against emotions and tensions that mobile phones present $[5,11,16]$.

Therefore, it has become clear that the problematic use of mobile phone is used as a tool to regulate emotions. Thus, the problematic use of mobile phones affects emotional intelligence and self-regulation, and therefore, the individual well-being and quality of life of adolescents [25], as well as interpersonal relationships, which manifests as bullying and cyberbullying situations [40-45].

This study motivates the need to promote programs aimed at managing emotions and improving interpersonal relationships to prevent cyberbullying situations.

Author Contributions: Conceptualization, I.M. and A.B.J.; methodology, I.M. and J.M.G.-F.; formal analysis, I.M. and J.M.G.-F.; research, A.B.J. and C.R.E.; data curation, A.B.J. and C.R.E.; writing: preparation of the original 
draft, all authors; writing: review and editing, all authors; supervision, all authors. All authors have read and agreed to the published version of the manuscript.

Funding: This research did not receive external funding.

Conflicts of Interest: The authors declare that they have no conflict of interest.

\section{References}

1. Almendola, S.; Spensieri, V.; Guidetti, V.; Cerutti, R. The relationship between difficulties in emotion regulation and dysfunctional technology use among adolescents. J. Psychopathol. 2019, 25, 10-17.

2. Besoli, G.; Palomas, N.; Chamarro, A. Mobile phone use in parents, children and adolescents: Beliefs about risks and benefits. Aloma 2018, 36, 29-39.

3. Carbonell, X.; Chamarro, A.; Griffiths, M.; Oberst, U.; Cladellas, R.; Talarn, A. Problematic Internet and cell phone use in Spanish teenagers and young students. Ana. Psicol. 2012, 28, 789-796. [CrossRef]

4. Lee, Y.K.; Chang, C.T.; Lin, Y.; Cheng, Z.H. The dark side of smartphone usage: Psychological traits, compulsive behavior and technostress. Comput. Hum. Behav. 2014, 31, 373-383. [CrossRef]

5. Echeburúa, E.; de Corral, P. Adicción a las nuevas tecnologías y a las redes sociales en jóvenes: Un nuevo reto. Adicciones 2010, 22, 91-96. [CrossRef] [PubMed]

6. Livingstone, S.; Smith, P.K. Annual Research Review: Harms experienced by child users of online and mobile technologies: The nature, prevalence and management of sexual and aggressive risks in the digital age. Psychiatry Clin. Psychol. 2014, 55, 635-654. [CrossRef]

7. Muñoz-Miralles, R.; Ortega-González, R.; López-Morón, M.R.; Batalla-Matínez, C.; Manresa, J.M.; Montellá-Jordana, N.; Chamarro, A.; Carbonell, X.; Torán-Monserrat, P. The problematic use of Information and Communication Technologies (ICT) in adolescents by the cross sectional JOITIC study. BMC Pediatrics 2016, 16, 140. [CrossRef]

8. De Sola-Gutierrez, J.; Rodríguez de Fonseca, R.; Rubio, G. Cell-Phone Addiction: A review. Front. Psychiatry 2016, 7, 175. [CrossRef]

9. Santana-Vega, L.; Gómez-Muñoz, A.M.; Feliciano-García, L. Adolescents' problematic mobile phone use, Fear of Missing Out and family communication. Comunicar 2019, 59, 39-47. [CrossRef]

10. García, M.C.; Monferrer, J.M. A theoretical analysis proposal on mobile phone use by adolescents. Comunicar 2009, 33, 83-92. [CrossRef]

11. Cía, A. Non-substance related addictions (DSM-5, APA 2013). A first step towards the inclusion of Behavioral addictions in current categorical classifications. Rev. Neuropsiquiatr. 2013, 76, 210-217. [CrossRef]

12. Díaz-López, A.; Maquilón-Sánchez, J.J.; Mirete-Ruiz, A.B. Maladaptive use of ICT in adolescence: Profiles, supervision and technological stress. Comunicar 2020, 64, 29-38. [CrossRef]

13. Moral, M.V.; Suárez, C. Factores de riesgo en el uso problemático de Internet y del teléfono móvil en adolescentes españoles. Rev. Iberoam. Psicol. Salud 2016, 7, 69-78. [CrossRef]

14. Martín-Perpiñá, M.M.; Poch, F.V.; Cerrato, S.M. Personality and Social Context Factors Associated to Self-Reported Excessive Use of Information and Communication Technology (ICT) on a Sample of Spanish Adolescents. Front. Psychol. 2019, 10, 436. [CrossRef] [PubMed]

15. Fernández-Sánchez, N. Trastornos de conducta y redes sociales en internet. Salud Ment. 2013, 30, 521-527. [CrossRef]

16. Serrano-Puche, J. Internet and Emotions: New Trends in an Emerging Field of Research. Comunicar 2016, 46, 19-25. [CrossRef]

17. Estévez, A.; Jáuregui, P.; López-González, H. Attachment and behavioral addictions in adolescents: The mediating and moderating role of coping strategies. Scand. J. Psychol. 2019, 60, 348-360. [CrossRef]

18. Yıldiz, M. Emotion regulation strategies as predictors of internet addiction and smartphone addiction in adolescents. J. Educ. Sci. Psychol. 2017, 7, 66-78.

19. Caplan, S.E. Theory and measurement of generalized problematic Internet use: A twostep approach. Comput. Hum. Behav. 2010, 26, 1089-1097. [CrossRef]

20. Oktan, V. The predictive relationship between emotion management skills and Internet Addiction. Soc. Behav. Pers. 2011, 39, 1425-1430. [CrossRef]

21. Yu, J.J.; Kim, H.; Hay, I. Understanding adolescents' problematic Internet use from a social/cognitive and addiction research framework. Comput. Hum. Behav. 2013, 29, 2682-2689. [CrossRef] 
22. Hormes, J.M.; Kearns, B.; Timko, C.A. Craving Facebook? Behavioral addiction to online social networking and its association with emotion regulation deficits. Addiction 2014, 109, 2079-2088. [CrossRef] [PubMed]

23. Fu, L.; Wang, P.; Zhao, M.; Xie, X.; Chen, Y.; Nie, J.; Lei, L. Can emotion regulation difficulty lead to adolescent problematic smartphone use? A moderated mediation model of depression and perceived social support. Child. Youth Serv. Rev. 2020, 108, 104660. [CrossRef]

24. Hoffner, C.A.; Lee, S. Mobile phone use, emotion regulation, and wellbeing. Cyberpsychol. Behav. Soc. Netw. 2015, 18, 411-416. [CrossRef]

25. Mascia, M.L.; Agus, M.; Penna, M.P. Emotional Intelligence, Self-Regulation, Smartphone Addiction: Which relationship with student Well-Being and Quality of Life? Front. Psychol. 2020, 11, 375. [CrossRef]

26. Gil, F.; Del Valle, G.; Oberst, U.; Chamarro, A. Nuevas tecnologías-_Nuevas patologías? El smartphone y el fear of missing out. Aloma 2015, 33, 77-83.

27. Casas, J.A.; Ruiz-Olivares, R.; Ortega-Ruiz, R. Validation of the Internet and Social Networking Experiences Questionnaire in Spanish adolescents. Int. J. Clin. Health Psychol. 2013, 13, 40-48. [CrossRef]

28. Cornejo, M.; Tapia, M.L. Redes sociales y relaciones interpersonales en internet. Fundam. Humanid. 2011, 12, 219-229.

29. Hsieh, K.Y.; Hsiao, R.C.; Yang, Y.H.; Lee, K.H.; Yen, C.F. Relationship between Self-Identity confusion and Internet Addiction among College Students: The mediating effects of Psychological Inflexibility and experiential avoidance. Int. J. Environ. Res. Public Health 2019, 16, 3225. [CrossRef]

30. Arab, L.E.; Díaz, A. Impact of social networks and internet in adolescence: Strengths and weaknesses. Rev. Med. Clin. Condes 2015, 26, 7-13.

31. Sabater Fernández, C.; López-Hernáez, L. Risk factors in Cyberbullying. Frequency and Exposition of Personal Data on the Internet. RISE 2015, 4, 1-25. [CrossRef]

32. Casas, J.A.; Del Rey, R.; Ortega-Ruiz, R. Bullying and cyberbullying: Convergent and divergent predictor variables. Comput. Hum. Behav. 2013, 29, 580-587. [CrossRef]

33. Chen, M.; Cheung, A.S.Y.; Chan, K.L. Doxing: What Adolescents Look for and Their Intentions. Int. J. Environ. Res. Public Health 2019, 16, 218. [CrossRef] [PubMed]

34. Buelga, S.; Iranzo, B.; Cava, M.J.; Torralba, E. Psychological profile of adolescent cyberbullying aggressors. J. Soc. Psychol. 2015, 30, 382-406.

35. Ortega-Barón, J.; Buelga, S.; Cava, M.J. The Influence of School Climate and Family Climate among adolescents victims of cyberbullying. Comunicar 2016, 24, 57-65. [CrossRef]

36. Kowalski, R.M.; Giumetti, G.W.; Schroeder, A.N.; Lattanner, M.R. Bullying in the digital age: A critical review and meta-analysis of cyberbullying research among youth. Psychol. Bull. 2014, 140, 1073-1137. [CrossRef]

37. Olweus, D.; Limber, S.P. Some problems with cyberbullying research. Curr. Opin. Psychol. 2018, 19, 139-143. [CrossRef]

38. Martínez-Ferrer, B.; Moreno, D.; Musitu, G. Are adolescents engaged in the problematic use of Social Networking Sites more involved in peer aggression and victimization? Front. Psychol. 2018, 9, 801. [CrossRef]

39. Sureda García, I.; López-Penádes, R.; Rodríguez Rodríguez, R.; Sureda Negre, I. Cyberbullying and Internet addiction in gifted and nongifted teenagers. Gift. Child Q. 2020, 64, 192-203. [CrossRef]

40. Wachs, S.; Junger, M.; Sittichai, R. Traditional, Cyber and Combined Bullying Roles: Differences in Risky Online and Offline Activities. Societies 2015, 5, 109-135. [CrossRef]

41. Arnaiz, P.; Cerezo, F.; Giménez, A.M.; Maquilón, J.J. Online addiction behaviors and cyberbullying among adolescents. Anal. Psicol. 2016, 32, 761-769.

42. Méndez, I.; Jorquera Hernández, A.B.; Ruiz-Esteban, C. Profiles of mobile phone problem use in Bullying and Cyberbullying among adolescents. Front. Psychol. 2020, 11, 596961. [CrossRef]

43. Giménez, A.M.; Maquilón, J.J.; Arnaiz, P. Usos problemáticos y agresivos de las TIC por parte de adolescentes implicados en cyberbullying. RIE Rev. Investig. Educ. 2015, 33, 335-351. [CrossRef]

44. Gül, H.; Fırat, S.; Sertçelik, M.; Gül, A.; Yusuf Gürel, Y.; Birim Günay, K. Cyberbullying among a clinical adolescent sample in Turkey: Effects of problematic smartphone use, psychiatric symptoms, and emotion regulation difficulties. Psychiatry Clin. Psychopharmacol. 2019, 29, 547-557. [CrossRef]

45. Kwok, S.W.H.; Lee, P.H.; Lee, R.L.T. Smart Device Use and Perceived Physical and Psychosocial Outcomes among Hong Kong Adolescents. Int. J. Environ. Res. Public Health 2017, 14, 205. [CrossRef] [PubMed] 
46. Bar-On, R. The Emotional Quotient Inventory (EQ-i): Technical Manual; Multi-Health Systems, Inc.: Toronto, ON, Canada, 1997.

47. Ferrándiz, C.; Hernández, D.; Bermejo, R.; Ferrando, M.; Sáinz, M. Social and emotional intelligence in childhood and adolescence: Spanish validation of a measurement instrument. Rev. Psicodidáct. 2012, 17, 309-339. [CrossRef]

48. Beranuy, M.; Chamarro, A.; Graner, C.; Carbonell, X. Validation of two brief scales for Internet addiction and mobile phone problem use. Psicothema 2009, 2, 480-485.

49. Álvarez-García, D.; Núñez, J.C.; Rodríguez, C.; Álvarez, L.; Dobarro, A. Violence through information and communication technologies in secondary students. Rev. Psicodidáct. 2011, 16, 59-83.

50. Hair, J.F.; Anderson, R.E.; Tatham, R.L.; Black, W.C. Multivariate Data Analysis, 5th ed.; Prentice-Hall: Upper Saddle River, NJ, USA, 1998.

51. Muthén, L.K.; Muthén, B.O. Mplus:Statistical Analysis with Latent Variables. User's Guide, 7th ed.; Muthén \& Muthén: Los Ángeles, CA, USA, 2012.

52. Cohen, J. Statistical Power Analysis for the Behavioral Sciences; Academic Press: Cambridge, MA, USA, 1998.

53. Estévez, J.F.; Cañas, E.; Estévez, E. The Impact of Cybervictimization on Psychological Adjustment in Adolescence: Analyzing the Role of Emotional Intelligence. Int. J. Environ. Res. Public Health 2020, 17, 3693. [CrossRef]

54. Moral Jiménez, M.V.; Fernández Domínguez, S. Problematic Internet use in Spanish adolescents and their relationship with self-esteem and impulsivity. Av. Psicol. Lationam. 2019, 37, 103-119. [CrossRef]

55. Del Rey, R.; Casas, J.A.; Ortega, R. Impact of the ConRed Program on Different Cyberbulling Roles. Aggress. Behav. 2016, 42, 132-135. [CrossRef] [PubMed]

56. Del Rey, R.; Mora-Merchán, J.A.; Ortega-Ruiz, R.; Elipe, P. ‘Asegúrate’ Program: Effects on cyber-aggression and its risk factors. Comunicar 2018, 26, 39-48. [CrossRef]

57. Del Rey, R.; Ortega-Ruiz, R.; Casas, J.A. Asegúrate: An Intervention Program against Cyberbullying Based on Teachers' Commitment and on Design of Its Instructional Materials. Int. J. Environ. Res. Public Health 2019, 16, 434. [CrossRef] [PubMed]

58. Garaigordobil, M.; Martínez-Valderrey, V. Technological Resources to Prevent Cyberbullying during adolescence: The Cyberprogram 2.0 Program and the Cooperative Cybereduca 2.0 Videogame. Front. Psychol. 2018, 9, 745. [CrossRef]

59. Ortega-Barón, J.; Buelga, S.; Ayllón, E.; Martínez-Ferrer, B.; Cava, M.-J. Effects of Intervention Program Prev@cib on Traditional Bullying and Cyberbullying. Int. J. Environ. Res. Public Health 2019, 16, 527. [CrossRef]

60. Grant, J.E.; Potenza, M.N.; Weinstein, A.; Gorelick, D.A. Introduction to behavioral addictions. Am. J. Drug Alcohol Abus. 2010, 36, 233-241. [CrossRef]

Publisher's Note: MDPI stays neutral with regard to jurisdictional claims in published maps and institutional affiliations.

(C) 2020 by the authors. Licensee MDPI, Basel, Switzerland. This article is an open access article distributed under the terms and conditions of the Creative Commons Attribution (CC BY) license (http://creativecommons.org/licenses/by/4.0/). 